\title{
ОЦЕНКА ВЛИЯНИЯ КОНЬЮГАТА ПРОИЗВОДНОГО ГИДРОКСИБЕНЗОЙНОЙ КИСЛОТЫ С ГЛИЦИНОМ, НА ПСИХОНЕВРОЛОГИЧЕСКИЙ ДЕФИЦИТ У ЖИВОТНЫХ С ОНМК НА ФОНЕ ХНМК
}

\author{
Д.В. Верхоляк \\ Кафедра химии, Волгоградский государственный медицинский университет, \\ 400131, Россия, г. Волгоград, площадь Павших Борцов, д. 1.
}

DOI: 10.19163/MedChemRussia2021-2021-550

E-mail:verholyakdima@mail.ru

Актуальность. На сегодняшний день ишемический инсульт головного мозга является одним из наиболее частых причин инвалидизации населения, поскольку даже в случае своевременного оказания квалифицированной медицинской помощи лишь 10\% пациентов восстанавливается практически полностью, а почти 40\% пациентов восстанавливается с умеренными и тяжелыми нарушениями. У $15 \%$ перенесших инсульт, он повторяется в течении года, а еще $15 \%$ умирают вскоре после перенесенного инсульта.

Цель работы. Исследование влияния на психоневрологический дефицит коньюгата производного гидроксибензойной кислоты с глицином (соединение с шифром (40), у животных с острым нарушением мозгового кровообращения, воспроизводимого на фоне хронического нарушения мозгового кровообращения.

Материалы и методы: Исследование выполнено на крысах возрастом 6-8 месяцев, которым моделировали хроническое нарушение мозгового кровообращения посредством стеноза общих сонных артерий (на 50\%) за 40 дней до моделирования фокальной ишемии головного мозга, вызванной необратимой окклюзией средней мозговой артерии. Терапия исследуемым соединением и препаратом сравнения (цитиколин) проводилась в течении 10 дней после моделирования ОНМК. После терапии оценивалось поведение животных в тестах «Открытое поле» и «Адгезивный тест», и подсчитывался неврологический индекс животных по шкале Garcia и шкале Combs и D’Alecy.

Результаты и их обсуждение. Было установлено, что курсовое введение исследуемого соединения С40 и препарата сравнения цитокинина, статистически значимо повышали исследовательскую и ориентировочно-двигательную активность животных в открытом поле (на 25\% и 29\% соответственно по сравнению с группой негативного контроля). В «Адгезивном тесте» соединение С40 значимо уменьшало время обнаружения и снятия постороннего предмета. К тому же неврологический индекс животных, получавших исследуемое соединение, был сопоставим с группой животных получавших цитиколин.

Вывод. Курсовое введение исследуемого коньюгата производного гидроксибензойной кислоты с глицином оказывало выраженное нейропротективное действие в условиях острого нарушения мозгового кровообращения воспроизводимого на фоне стеноза общих сонных артерий. 